\title{
Intervening Effect of Attitude on the Relationship between Selected Determinants and Corporate Image
}

\author{
Prasit Rattanaphan and Nik Kamariah Nik Mat
}

\begin{abstract}
Despite the profitable revenue reported by direct selling industry, the corporate image of these companies has been negative and deteriorating. This is partly attributable to the increasing number of pyramid schemes and frauds which had led to the negative attitude of the consumer towards direct selling, and tarnished the image of the direct selling company in recent years. Hence, the main objective of this study is to examine the intervening effect of attitude in the relationship between the selected determinants and corporate image of direct selling companies in Thailand. A total of 900 questionnaires was distributed to direct selling customers, and 612 were collected back, representing a response rate of $68 \%$. A final 532 usable questionnaires were analysed using structural equation modelling (SEM). This study found a full mediating effect of attitude between perceived value and corporate image. However, attitude was a partial mediator when tested for linkage between trust and corporate image while attitude does not mediate in others. The finding of the study is discussed in the perspective of its implications in direct selling context.
\end{abstract}

Index Terms-Attitude, corporate image, direct selling, Thailand.

\section{INTRODUCTION}

Despite the profitable revenue reported by direct selling industry, the corporate image of these companies has been negative and deteriorating [1]-[3]. This negative corporate image has been triggered by illegal pyramid schemes, negative attitude, lack of trust, negative perceived value, internet fraud, lack of corporate social responsibility (CSR) and confused brand architecture conducted by direct selling companies. Many people have negative attitudes and bad image with regards to internet marketing conducted by direct selling companies [2], [3]. The declining corporate image of direct selling companies has accelerated the negative attitude towards them [2], [3]. The negative attitude can affect the long term productivity of industries which rely on this method of sales as a mean of promoting their company. The statements confirm that customer attitudes can have a drastic effect on corporate image [4]. Trust towards direct selling companies is dwindling amongst the stakeholders [5]. Perceived value is also a problem when many complaints were made through the internet regarding direct selling products such as legal officials have cautioned people to check the direct selling companies prior to determine whether

Manuscript received June 11, 2014; revised August 10, 2014.

Prasit Rattabaphan is with Hatyai Business School, Hatyai University, Hatyai, Songkhla, 90110 Thailand (e-mail: prasit_aod@hotmail.com, prasit@hu.ac.th).

Nik Kamariah Nik Mat is with OYA Graduate Business College of Business, Universiti Utara Malaysia. Sintok, Kedah Darul Aman, 06010 Malaysia (e-mail: drnikuum@gmail.com). they have legally registered with the Thailand Office of Consumer Protection Board (OCPB), or if complaints had been lodged previously. Very few direct selling companies are conscious or focuses on CSR activities [6]-[8]. Direct selling companies launch multi brand product strategy (e.g. Amway, Skyline, $\mathrm{Nu}$ Skin) which leads to customer confusion because the customer seems to in tolerate multi brand in direct selling probably [9] because direct selling companies could be their avenue to get new innovation which are not found in the retail market [8].

\section{RESEARCH PROBLEM}

Corporate image in direct selling has been tarnished by fraud, pyramid schemes and scams [8]-[12] in most countries including Thailand. Although the increase in consumer demand is encouraging, impurity is still emerging and the numbers of fraudulent businesses are growing and continuing to damage corporate image of direct selling companies [1], [5], [11]. This managerial gap has indicated that direct selling companies are worried about pyramid schemes and internet fraud which can be the main cause of bad direct selling corporate image that might threaten their legitimate business [13]. The increasing number of pyramid schemes and internet frauds (internet marketing) cases have created problems leading to the negative attitude [10], distrust [14], negative perceived value [15] and consequently leading to the bad corporate image of direct selling companies [12]. Distrust in consumer attitude as a result of internet fraud in Thailand [16] has affected consumers' attitudes towards the products or services they purchase [2], [3]. This suggests that trust, internet marketing and perceived value could be important predictors of attitude's linkage to corporate image.

The second problem concerns the theoretical gap in which the predictors of corporate image have been diversified and fragmented. The past models also indicate fragmentation since different numbers of factors were examined in each model. Moreover, many of these research models were mostly in non-direct selling setting. Furthermore, previous comprehensive corporate image models have not used attitude as a mediator in direct selling areas. The literature shows a few studies [17], whereby attitude mediates between predictors (brand, perceived difficulty, category fit, perceived image fit) and corporate image. Similarly, Karaosmanoglu, Bas and Zhang [18] propose attitude as mediator between other customer effects and corporate image. Adversely, attitude is viewed as a dependent variable, not a mediator in the following studies [15], [19]-[21].

The intent of this study is to address the existing limited empirical investigations and improve the quantitative results 
on attitude's linkage to corporate image predictors, especially with respect to direct selling companies and consumers in Thailand. Thus, it is most important for the direct selling company to build a good corporate image [22], and determine the direct or indirect factors that affect corporate image in direct selling companies.

\section{RESEARCH QUESTION AND RESEARCH OBJECTIVE}

The research questions that were asked in this study include the followings: Does attitude intervene (mediate) in the relationship between the determinants (brand architecture, CSR, Internet marketing, trust, perceived value) and corporate image?

The main objective is to examine the intervening effect of attitude in the relationship between the determinants (brand architecture, CSR, Internet marketing, trust, perceived value) and corporate image of direct selling companies in Thailand.

\section{LITERATURE REVIEW}

Corporate image is a resource which is most difficult to imitate, as a result of the extensive time period that is necessary for development and an intuitively appealing concept which is related to attitude. The concept of corporate image is implicated to different types, such as perceived by consumers, community and stakeholders, and also depending on consumers' purpose. Hu, Kandampully and Juwaheer [23] suggest that corporate image is a major process that affects attitudes, perception and customer satisfaction, because it relates to the consumers' recognition of the products and services. Therefore, corporate image is a result of attitude, perception and recognition.

The key reason for focusing on the corporate image model is mainly because corporate image model still requires further research since there exist inconsistencies in past results [14], [17], [18]. There is a widespread importance of studying attitude issues toward direct selling companies [24], fragmented conceptualization [17], [25], lack of practitioners [26], and empirical understanding of attitudinal aspects of corporate image, and increasing negative attitude in direct selling [2], [3].

The literature has shown that there are many factors that affect consumer attitudes, such as brand architecture [17], [27], [28], internet marketing [29], CSR [14], trust [14]-[16], [19], and perceived value [15], [30], [31].

Moreover, inconsistent result also observes the mediating effect of attitude on the relationship of the other linkages [14], [17], [27], [28], [30]-[34]. Thus, this hypothesis ought to be investigated further due to inconsistent results as well as to increase direct selling sectors especially in Thailand. This study also includes the mediating effect of attitude based on the arguments of previous studies that were limited.

This research framework is primarily based on the attitude towards a behaviour model [35] which acts as the mediating factor between predictors (brand architecture, perceived value, CSR, internet marketing and trust) and the corporate image. There appears to be a lack of studies using attitude as a mediating variable between predictors (brand architecture, CSR, internet marketing, trust, perceived value) and corporate image in past studies. The common direct predictors of attitude investigated in previous academic research are brand architecture [17], [27], [28], trust [14], [15], [19], [20], CSR [21], perceived value [15], [30], [31], internet marketing [20], [21], [29]. Their direct relationships with consumer attitude are equivocal or mixed.

TABLE I: PREVIOUS STUDIES WITH ATTITUDE AS MEDIATOR

\begin{tabular}{|c|c|c|c|}
\hline Authors & Respondent & Finding & Direction \\
\hline $\begin{array}{l}\text { Martínez and } \\
\text { Pina [17] }\end{array}$ & $\begin{array}{l}\text { Consumer product } \\
699 \text { consumers (Spain) } \\
\text { IV: Perceived image fit } \\
\text { DV: image variation }\end{array}$ & $\begin{array}{l}\text { Full } \\
\text { mediator }\end{array}$ & $\begin{array}{l}\text { Significant } \\
\text { (positive) }\end{array}$ \\
\hline $\begin{array}{l}\text { Jayawardhena } \\
{[30]}\end{array}$ & $\begin{array}{l}\text { E-shopping } 626 \text { e-shoppers } \\
\text { (UK) } \\
\text { IV: values } \\
\text { DV: e-shopping behavior }\end{array}$ & $\begin{array}{l}\text { Full } \\
\text { mediator }\end{array}$ & $\begin{array}{l}\text { Significant } \\
\text { (positive) }\end{array}$ \\
\hline $\begin{array}{l}\text { Limbu, } \\
\text { Wolfand and } \\
\text { Lunsford [14] }\end{array}$ & $\begin{array}{l}\text { Retailing } \\
259 \text { online shoppers (USA) } \\
\text { IV: trust } \\
\text { DV: purchase intension }\end{array}$ & $\begin{array}{l}\text { Partial } \\
\text { mediator }\end{array}$ & $\begin{array}{l}\text { Significant } \\
\text { (positive) }\end{array}$ \\
\hline Lin [28] & $\begin{array}{l}\text { Services industry } \\
299 \text { tourists (Taiwan) } \\
\text { IV: Perceived risk } \\
\text { DV: behavior intention }\end{array}$ & $\begin{array}{l}\text { Partial } \\
\text { mediator }\end{array}$ & $\begin{array}{l}\text { Significant } \\
\text { (positive) }\end{array}$ \\
\hline $\begin{array}{l}\text { Martinez, Polo } \\
\text { and } \\
\text { Chernatony } \\
{[33]}\end{array}$ & $\begin{array}{l}\text { Sport clothes } \\
777 \text { consumers (UK \& Spain) } \\
\text { IV: brand before extension } \\
\text { DV: brand after extension }\end{array}$ & $\begin{array}{l}\text { Not } \\
\text { mediating }\end{array}$ & $\begin{array}{l}\text { Significant } \\
\text { (positive) }\end{array}$ \\
\hline Dwivedi [27] & $\begin{array}{l}\text { Footwear } \\
387 \text { students (India) } \\
\text { IV: Brand image } \\
\text { DV: attitude change }\end{array}$ & $\begin{array}{l}\text { Not } \\
\text { mediating }\end{array}$ & $\begin{array}{l}\text { Significant } \\
\text { (positive) }\end{array}$ \\
\hline $\begin{array}{l}\text { Ado-Yobo, } \\
\text { Njiru and } \\
\text { Sohail [32] }\end{array}$ & $\begin{array}{l}\text { Water services } \\
368 \text { low-income people (Ghana) } \\
\text { IV : behavioral belief } \\
\text { DV : behavioral intention }\end{array}$ & $\begin{array}{l}\text { Not } \\
\text { mediating }\end{array}$ & $\begin{array}{l}\text { Significant } \\
\text { (positive) }\end{array}$ \\
\hline $\begin{array}{l}\text { Lada, } \\
\text { Tanakinjal } \\
\text { and Amin [34] }\end{array}$ & $\begin{array}{l}\text { Halal food products } \\
485 \text { consumers (Malaysia) } \\
\text { IV : subjective norms } \\
\text { DV: intention choose product }\end{array}$ & $\begin{array}{l}\text { Not } \\
\text { mediating }\end{array}$ & $\begin{array}{l}\text { Significant } \\
\text { (positive) }\end{array}$ \\
\hline
\end{tabular}

The results of previous studies investigate attitude as a mediating that show inconsistent results such as full mediator [17], [30], partial mediator [14], [28], no mediation [27]. The hypothesis ought to be investigated further due to inconsistent results as well as to increase direct selling sectors especially in Thailand. This study also includes the mediating effect of attitude based on the arguments of previous studies that were limited. Thus, the hypothesis of this study is attitude mediates between all linkages in the research framework are:

- Hypothesis 1: Attitude (ATT) mediates the relationship between brand architecture (BA) and corporate image (CI).

- Hypothesis 2: Attitude (ATT) mediates the relationship between perceived value (PV) and corporate image (CI).

- Hypothesis 3: Attitude (ATT) mediates the relationship between internet marketing (IM) and corporate image (CI).

- Hypothesis 4: Attitude (ATT) mediates the relationship between CSR (CSR) and corporate image (CI).

- Hypothesis 5: Attitude (ATT) mediates the relationship between trust (TST) and corporate image (CI). 


\section{RESEARCH Methodology}

The study adopts the quantitative research methodology with empirical research design by collecting primary data to answer the research questions and to achieve the research objectives. It is conducted with data collected from the structured questionnaire and analysed by structural equation modeling approach.

\section{A. Questionnaire Design}

The initial questionnaire consists of three parts; Part 1: General data contain 6 items, Part 2: Direct selling profile consists of 7 items, and Part 3: Latent variables (brand architecture, perceived value, corporate social responsibility, internet marketing, trust, attitude and corporate image) contains 48 items that used seven point rating Likert scales (1 $=$ strongly disagree and $7=$ strongly agree). It was pre-tested on eight direct selling managers and eight marketing lecturers, in order to ensure that the concepts used are clear and relevant for direct selling and for face validity.

A pilot study was conducted with a sample size of 165 consisting of direct selling's customers from staff of three organizations distributed equally (55 respondents per organization) in Songkhla, Thailand (government organization, university, and bank). The changes have been made to the final questionnaire after analysis of pilot data. The data analysed using SPSS to obtain the reliability results and factor analysis (Convergent validity). From the results of the pilot study, the final questions or items with high factor loading of above 0.70 were included in the actual questionnaire that now consists of 38 items.

\section{B. Sampling Method and Data Collection}

The sampling frame was taken from three sectors (Government Organizations, Universities, and Banks) in Thailand because it represents the three zones in Thailand (Northern, Central, and Southern) for manageability. Thus, the three sectors were then specified so as to cover the three zones in Thailand. This study could also determine sample size through confidence intervals and the margin of error that indicated a sample size of 384 is arrived at a precision level of $95 \%$ confidence level, the usual accepted level of confidence in social science research [36].

This study used proportionate stratified sampling and conducted with a sample size of 900 consisting of direct selling's customers from three sectors selected at each sectors equally (300 questionnaires per sector) The data were collected from all three sectors during the same period of two months.

\section{RESEARCH RESULT}

This study collected 612 responses from the distributed sample size of 900 , representing the overall response rate of $68 \%$. The detection of outliers through Mahalanobis Distance $\left(D^{2}\right)$ resulted in the deletion of 56 more cases leaving the remaining total final usable cases at 532 .

The majority of respondents involve in direct selling business for less than 1 year $(n=198,37.2 \%)$. Top 5 direct selling companies in Thailand were Amway (the highest number of customers) $(n=326,30 \%)$, Skyline $(n=195$,
$18 \%)$, Better Way $(n=149,13.7 \%)$, Aimstar $(n=101,9.3 \%)$, and Zulian $(n=99,9.1 \%)$. The direct selling products that respondents regularly purchased were cosmetics and personal care products $(44.6 \%)$, followed by supplements (26\%). Most respondents $(57.7 \%)$ purchased direct selling product from salesperson and 35\% purchased from direct selling outlets, a major reason of purchasing was higher quality products $(26.7 \%)$. Most of the direct selling customer $(41.5 \%)$ spent between 500-1,000 Baht per purchase and making a purchase once every month $(63.5 \%)$.

The results of this study showed that the factor loading of all final items achieves values above 0.50 (between 0.597 and 0.902). The items remaining consist of brand architecture (3 items), perceived value (2 items), internet marketing (2 items), corporate social responsibility (3 items), trust (3 items), attitude ( 2 items), and corporate image ( 3 items).

All constructs and variables used in this study are based on well-established instruments with high reliability values and the composite reliability of each construct was substantiated to be above 0.90 (Table II).

TABLE II: RELIABILITY LEVELS OF INSTRUMENTS

\begin{tabular}{lcc}
\hline \hline \multirow{2}{*}{ Construct } & \multicolumn{2}{c}{ Internal consistency } \\
& Cronbach Alpha & Composite Reliability \\
\hline Brand Architecture & 0.857 & 0.981 \\
CSR & 0.945 & 0.982 \\
Perceived Value & 0.894 & 0.978 \\
Internet Marketing & 0.897 & 0.978 \\
Trust & 0.932 & 0.985 \\
Attitude & 0.903 & 0.981 \\
Corporate Image & 0.912 & 0.983 \\
\hline \hline
\end{tabular}

TABLE III: CORRELATION MATRIX (R SQUARE IN PARENTHESES)

\begin{tabular}{|c|c|c|c|c|c|c|c|}
\hline Variables & 1 & 2 & 3 & 4 & 5 & 6 & 7 \\
\hline BA (1) & 1.000 & & & & & & \\
\hline PV (2) & $\begin{array}{c}0.548 \\
(0.300)\end{array}$ & 1.000 & & & & & \\
\hline IM (3) & $\begin{array}{c}0.579 \\
(0.335)\end{array}$ & $\begin{array}{c}0.693 \\
(0.480)\end{array}$ & 1.000 & & & & \\
\hline CSR(4) & $\begin{array}{c}0.501 \\
(0.251)\end{array}$ & $\begin{array}{c}0.730 \\
(0.533)\end{array}$ & $\begin{array}{r}0.628 \\
(0.394)\end{array}$ & 1.000 & & & \\
\hline TST (5) & $\begin{array}{c}0.550 \\
(0.303)\end{array}$ & $\begin{array}{c}0.765 \\
(0.585)\end{array}$ & $\begin{array}{r}0.738 \\
(0.545\end{array}$ & $\begin{array}{r}0.669 \\
(0.448\end{array}$ & 1.000 & & \\
\hline ATT(6) & $\begin{array}{c}0.529 \\
(0.280)\end{array}$ & $\begin{array}{c}0.795 \\
(0.632)\end{array}$ & $\begin{array}{r}0.747 \\
(0.558\end{array}$ & $\begin{array}{r}0.669 \\
(0.448\end{array}$ & $\begin{array}{c}0.903 \\
(0.815)\end{array}$ & 1.000 & \\
\hline CI (7) & $\begin{array}{c}0.591 \\
(0.349)\end{array}$ & $\begin{array}{c}0.749 \\
(0.561)\end{array}$ & $\begin{array}{r}0.743 \\
(0.552\end{array}$ & $\begin{array}{c}0.683 \\
(0.466\end{array}$ & $\begin{array}{c}0.824 \\
(0.679)\end{array}$ & $\begin{array}{c}0.875 \\
(0.766)\end{array}$ & 1.000 \\
\hline
\end{tabular}

Discriminant validity is the presence of multicollinearity, it indicates a discriminant problem. The method used is to compare average variance extracted (AVE) with correlation squared [37]. If AVE is more than correlation squared then, discriminant validity is supported. The variance extracted is calculated using the following equation:

$$
A V E=\frac{\sum\left[\lambda_{i}^{2}\right] \operatorname{Var}(X)}{\sum\left[\lambda_{i}^{2}\right] \operatorname{Var}(X)+\sum\left[\operatorname{Var}\left(\varepsilon_{i}\right)\right]}
$$


where $\lambda_{i}$ is the loading of $x_{i}$ on $X, \operatorname{Var}$ denotes variance, $\varepsilon_{i}$ is the measurement error of $x_{i}$, and $\Sigma$ denotes a sum [37].

TABLE IV: AVERAGE VARIANCE EXTRACTED (AVE)

\begin{tabular}{lccccccc}
\hline \hline Variable & 1 & 2 & 3 & 4 & 5 & 6 & 7 \\
\hline BA (1) & 1.000 & & & & & & \\
PV(2) & 0.896 & 1.000 & & & & & \\
I M (3) & 0.895 & 0.927 & 1.000 & & & & \\
CSR(4) & 0.901 & 0.933 & 0.932 & 1.000 & & & \\
TST (5) & 0.900 & 0.932 & 0.931 & 0.937 & 1.000 & & \\
ATT(6) & 0.904 & 0.936 & 0.935 & 0.940 & 0.940 & 1.000 & \\
CI (7) & 0.884 & 0.916 & 0.915 & 0.921 & 0.920 & 0.924 & 1.000 \\
\hline
\end{tabular}

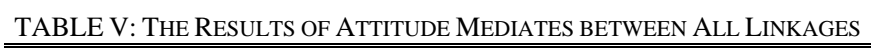

\begin{tabular}{ccc}
$\mathrm{H} 1: \mathrm{BA} \rightarrow \mathrm{ATT} \rightarrow \mathrm{CI}$ & $\Delta \chi^{2}=1.023, \Delta \mathrm{df}=1, \Delta \mathrm{p}=0.000$ & $\begin{array}{c}\text { Not } \\
\text { Mediating }\end{array}$ \\
\hline Model Element & $\begin{array}{c}\text { Model of testing } \\
\text { for mediating }\end{array}$ & $\begin{array}{c}\text { Revised model } \\
\text { with direct } \\
\text { effect }\end{array}$ \\
$\mathrm{BA} \rightarrow$ ATT & $0.038(\mathrm{~ns})$ & $0.029(\mathrm{~ns})$ \\
$\mathrm{ATT} \rightarrow$ CI & $0.462^{* * *}$ & $0.455^{* * *}$ \\
$\mathrm{BA} \rightarrow$ CI & Not estimated & $0.042(\mathrm{~ns})$
\end{tabular}

$\mathrm{H} 2: \mathrm{PV} \rightarrow \mathrm{ATT} \rightarrow \mathrm{CI} \quad \Delta \chi^{2}=0.069, \Delta \mathrm{df}=1, \Delta \mathrm{p}=0.012 \quad$ Full Mediating

\begin{tabular}{ccc}
\hline Model Element & $\begin{array}{c}\text { Model of testing } \\
\text { for mediating }\end{array}$ & $\begin{array}{c}\text { Revised model } \\
\text { with direct } \\
\text { effect }\end{array}$ \\
PV $\rightarrow$ ATT & $0.338^{* * *}$ & $0.342^{* * *}$ \\
$\mathrm{ATT} \rightarrow \mathrm{CI}$ & $0.436^{* * *}$ & $0.455^{* * *}$ \\
$\mathrm{PV} \rightarrow \mathrm{CI}$ & Not estimated & $-0.019(\mathrm{~ns})$ \\
\hline
\end{tabular}

$\mathrm{H} 3: \mathrm{IM} \rightarrow \mathrm{ATT} \rightarrow \mathrm{CI} \quad \Delta \chi^{2}=4.505, \Delta \mathrm{df}=1, \Delta \mathrm{p}=-0.035 \quad$ No Mediating

\begin{tabular}{|c|c|c|}
\hline Model Elemen & $\begin{array}{l}\text { Model of testing } \\
\text { for mediating }\end{array}$ & $\begin{array}{l}\text { Revised model } \\
\text { with direct } \\
\text { effect }\end{array}$ \\
\hline $\mathrm{IM} \rightarrow \mathrm{ATT}$ & $0.107 *$ & $0.082(\mathrm{~ns})$ \\
\hline $\mathrm{ATT} \rightarrow \mathrm{CI}$ & $0.512 * * *$ & $0.455 * * *$ \\
\hline $\mathrm{IM} \rightarrow \mathrm{CI}$ & Not estimated & $0.101 *$ \\
\hline $\mathrm{H} 4: \mathrm{CSR} \rightarrow \mathrm{ATT} \rightarrow \mathrm{CI}$ & $\Delta \chi^{2}=10.5, \Delta \mathrm{df}=1, \Delta \mathrm{p}=-0.075$ & $\begin{array}{c}\text { Not } \\
\text { Mediating }\end{array}$ \\
\hline Model Elemen & $\begin{array}{l}\text { Model of testing } \\
\text { for mediating }\end{array}$ & $\begin{array}{c}\text { Revised model } \\
\text { with direct } \\
\text { effect }\end{array}$ \\
\hline $\mathrm{CSR} \rightarrow \mathrm{ATT}$ & $-0.073(\mathrm{~ns})$ & $0.082(\mathrm{~ns})$ \\
\hline $\mathrm{ATT} \rightarrow \mathrm{CI}$ & $0.352 * *$ & $0.455 * * *$ \\
\hline $\mathrm{CSR} \rightarrow \mathrm{CI}$ & Not estimated & $0.151 * *$ \\
\hline $\mathrm{H} 5: \mathrm{TST} \rightarrow \mathrm{ATT} \rightarrow \mathrm{CI}$ & $\Delta \chi^{2}=7.015, \Delta \mathrm{df}=1, \Delta \mathrm{p}=-0.054$ & $\begin{array}{c}\text { Partial } \\
\text { Mediating }\end{array}$ \\
\hline Model Elemen & $\begin{array}{l}\text { Model of testing } \\
\text { for mediating }\end{array}$ & $\begin{array}{c}\text { Revised model } \\
\text { with direct } \\
\text { effect }\end{array}$ \\
\hline $\mathrm{TST} \rightarrow \mathrm{ATT}$ & $0.657 * * *$ & $0.605^{* * *} *$ \\
\hline $\mathrm{ATT} \rightarrow \mathrm{CI}$ & $0.806^{* * *}$ & $0.455^{* * *}$ \\
\hline $\mathrm{TST} \rightarrow \mathrm{CI}$ & Not estimated & $0.307 * *$ \\
\hline
\end{tabular}

* Sig. at .05 level; ** Sig. at .005 level; *** Sig. at .001 level
The results showed that all constructs (AVE > correlation $^{2}$ ) were distinct to one another which depicted the reliability and validity of the survey instrument. The all value of AVE was greater than the corresponding (correlation ${ }^{2}$ ). Therefore discriminant was supported. Discriminant validity is satisfactory for the constructs in the measurement model (see Table III and Table IV).

The absolute fit indices (AFI) indicated a chi-square value $\left(\chi^{2}\right)$ of 132.481, degree of freedom (df) of 114, chi-square ratio $(\mathrm{CMIN} / \mathrm{df})$ of 1.162 , and $\mathrm{p}$-value of the 0.114 . The goodness of fit index (GFI) was 0.974 and root mean squared of error approximation (RMSEA) of 0.017. Therefore, all AFI surpasses threshold values indicating good fit. The hypothesized structural model also shows an $\mathrm{R}^{2}$ value of 0.810 for explaining attitude and 0.843 for explaining corporate image.

This study intends to test mediating effects of attitude between all linkages of the five direct hypotheses. The results are presented diagrammatically in Table V.

\section{DisCUSSION OF RESUlts}

Attitude is considered as an intervening factor in this research. Very few previous studies have conducted mediating effects of attitude whereby attitude is placed as a mediating effect on corporate image [17]. The discussion is based on the generated model that achieved the goodness-of-fit (GOF) of this study model

The results could imply that the consumer will continue using the services provided by the direct selling companies mainly due to the effort of the direct selling companies to continually offer value and it is dependent on the perception of what will be and what they will give [38]. It will be much easier for the direct selling companies to ensure repeated purchases and positive attitude towards the corporate image when they have constant perceived value and relationship with the consumer's attitude. The perceived value is an important factor which indirectly affects the relationship between attitude and corporate image which are keys to success of the direct selling companies. Attitude is a full mediator between perceived value and corporate image due to the reason that direct selling customers often based their purchase of product upon how the customer perceives the direct selling company.

There are many cases where direct selling customers develop a negative perception of direct consequence of frustration experienced when their direct selling representatives supplying them with a particular product may quit. Contradictory to that, when consumers plan to acquire a product through direct selling methods, they examine the perceived value of different options and corporate image which is often a main factor in their selection. Finally, perceived value has been essential in evaluating determinants of purchase behaviour and product choice and direct selling customers purchase a product based on separate favourites and recognizing a good corporate image.

The relationship between trust and corporate image is partially mediated by attitude. The results can imply that consumer's attitude will continue to develop trust in the direct selling company and their corporate image. It would 
also improve the image of direct selling companies. The importance of initiating, building and maintaining trust between the customer and the direct selling company is a key factor in successful direct selling companies [38]. Hence, direct selling companies should seek to build and maintain consumer's trust towards their corporate image [39]. However, the most convincing reason for attitude as a partial intervening effect between trust and corporate image of direct selling companies is because trust is a significant direct effect on corporate image, and attitude.

Furthermore, there was a substantive improvement in model fit and a significant path estimate for the trust and corporate image relationship after attitude is included. This is confirmed by numerous studies which have investigated the role of trust in the context of trust from business-to-consumer in direct selling such as Boripant [6]. He proposed that direct personal selling can be successful if it is focused on customer's trust. Hence, direct selling companies can concentrate on building and maintaining customers' trust to keep a positive view which can give a good corporate image for direct selling companies [40]. This is due to the fact that trust towards direct selling companies is dwindling amongst the stakeholders and low levels of trust can encourage regulation in the management and operation of direct selling companies.

\section{CONCLUSION}

The testing on mediating effect found that attitude is to be considered as a full mediator for linkages between perceived value and corporate image, while the relationship between trust and corporate image is partially mediated by attitude.

Attitude is a partial mediator as it is used to test for linkages between trust and corporate image. However, the attitude is not a mediator for the three linkages with corporate image, namely brand architecture, internet marketing and corporate social responsibility. This study is based upon the grounds that attitude towards corporate image is an essential element for the success in ongoing direct selling companies and also considering several factors as the determinants, which will all contribute to the enhancement of the corporate image among the direct selling companies.

As a conclusion, this study is very important for the direct selling companies to improve corporate image, and the government also needs to give direction in policy making towards the betterment of the direct selling industry. Moreover, this study informs customers about good trust and efficient marketing activities such as in internet marketing and corporate social responsibility from the direct selling companies, and create a positive attitude toward direct selling companies.

\section{IMPLICATION OF STUDY}

The results can give impetus to improving corporate image of the direct selling sector. The determinants of corporate image are mostly to create and maintain customers, and must be a priority agenda for most direct selling companies due to stiff competition and economic situational instability locally and globally. The results would increase the empirical literature in direct selling's marketing and related discipline.
The research model of this study's first attempt is based on the dimension of corporate image which utilize a Smith's corporate image model [25]. The data has been analysed using structural equation modeling (SEM) analysis and the result is more concrete and robust.

The direct selling companies can better handle competition and increase the sales, which can significantly improve the corporate image. The findings can give new ideas for handing competition and negative attitudes.

Customers need to be able to bargain for a good image of direct selling. The usage of attitude in direct selling activities and the attitude toward corporate image is especially suitable for measuring customers' attitude towards direct selling companies. The customers' attitude toward an organization is intimately connected to the corporate image which is the overall results of the interaction between customer and direct selling companies.

The results could give direction in policy making towards the betterment of the direct selling industry. Direct selling is important to the Thai economy and is linked with the economic crime. Thus, the corporate image of direct selling companies must be well developed. The direct selling companies need to monitor and regulated these companies to prevent ambiguity and ensure illegal banking activities do not happen.

\section{ACKNOWLEDGMENT}

We are thankful to Prof. Dr. Nik Kamariah Nik Mat for empowering us to complete this paper, giving helpful comments and assistance on an earlier version of this paper. We would like to thank all Hatyai University administrators for their scholarship and helpful comments.

\section{REFERENCES}

[1] J. J. S. Chang, "An analysis of advance fee fraud on the internet," Journal of Financial Crime, vol. 15, no. 1, pp. 71-81, 2008.

[2] S. Saha. (2009). Fraud scheme shadow over direct selling. [Online]. Available:

http://www.telegraphindia.com/1090727/jsp/business/story_11286405 .jsp

[3] P. Villarreal. (2009). Multilevel Marketing Is Bad. [Online]. Available: http://consumerist.com/2009/05/multilevel-marketing-is-bad.html\#co mments-content

[4] M. J. Barone, A. D. Miyazaki, and K. A. Taylor, "The influence of cause-related marketing on consumer choice: does one good turn deserve another?" Journal of the Academy of Marketing Science, vol. 28, no. 2, pp. 248-262, 2000.

[5] L. Young and G. Albaum, "Measurement of trust in salesperson-customer relationships in direct selling," Journal of Personal Selling and Sales Management, vol. 23, no. 3, pp. 253-269, 2003.

[6] A. Boripant, "Network marketing business: the development of direct selling," Princess of Naradhiwas University Journal, vol. 1, no. 3, pp. 19-32, 2009.

[7] R. A. Rahim, F. W. Jalaludin, and K. Tajuddin, "The important of corporate social responsibility on consumer behavior in Malaysia," Asian Academy of Management Journal, vol. 16, no. 1, pp. 119-139, January 2011.

[8] TDSA, "Publication manual of the Thailand direct selling association," Annual Report, Bangkok: Thailand Direct Selling Association, 2012.

[9] P. Rattanaphan and N. K. Nik Mat, "The relationship of direct antecedent variables on corporate image of direct selling companies in Thailand," in Proc. 2012 International Conference on Economics, Business and Marketing Management, IACSIT Press, 2012, vol. 29, pp. 11-17.

[10] L. Ferrell, T. L. Gonzalez-Padron, and O. C. Ferre, "An assessment of the use of technology in the direct selling industry," Journal of 
Personal Selling and Sales Management, vol. 30, no. 2, pp. 157-165, 2010.

[11] Corporate strategies in direct selling 2011, Passport GMID database, Euromonitor International, February 2012.

[12] C. Viosca, B. Bergiel, and P. Balsmeier, "Effects of electronic Nigerian money fraud on the brand equity of Nigeria \& Africa," Management Research News, vol. 27, no. 6, pp. 11-21, 2004.

[13] P. Edwards, E. Sarah, and E. Peter, Home-Based Business for Dummies, $3^{\text {rd }}$ ed. U.K.: Wiley, pp. 38-39, 2010.

[14] Y. B. Limbu, M. Wolfand, and D. Lunsford, "Perceived ethics of online retailers and consumer behavioral intentions," Journal of Research in Interactive Marketing, vol. 6, no. 2, pp. 133-154, 2012.

[15] P. Mechinda, S. Serirat, and J. Anuwichanont, "An examination of tourists, loyalty towards medical tourism in Pattaya, Thailand," International Business \& Economics Research Journal, vol. 9, no. 1, pp. 55-70, 2009.

[16] DSI. Thailand (2012). The Department of Special Investigation Report 2011. [Online]. Available: https://www.dsi.go.th/images/ stories /file/ sar\%202553\%20(9m).pdf

[17] E. Martínez and J. M. Pina, "Consumer responses to brand extensions: a comprehensive model," European Journal of Marketing, vol. 44, no. 7/8, pp. 1182-1205, 2010.

[18] E. Karaosmanoglu, A. B. E. Bas, and J. Zhang, "The role of other customer effect in corporate marketing: Its impact on corporate image and consumer-company identification," European Journal of Marketing, vol. 45, no. 9/10, pp. 1416-1445, 2011.

[19] S. Grabner-Kräuter and R. Faullant, "Consumer acceptance of internet banking: the influence of internet trust," International Journal of Bank Marketing, vol. 26, no. 7, pp. 483-504, 2008.

[20] A. Chattananon, M. Lawley, N. Supparerkchaisakul, and L. Leelayouthayothin, "Impacts of a Thai cause-related marketing program on corporate image," International Journal of Emerging Markets, vol. 3, no. 4, pp. 348-363, 2008.

[21] A. Chattananon, M. Lawley, N. Supparerkchaisakul, and L. Leelayouthayothin, "Building corporate image through societal marketing programs," Society and Business Review, vol. 2, no. 3, pp. 230-253, 2007.

[22] L. Lin and C. Lu, "The influence of corporate image, relationship marketing, and trust on purchase intention: the moderating effects of word-of-mouth," Tourism Review, vol. 65, no. 3, pp. 16-34, 2010.

[23] H. Hu, J. Kandampully, and T. D. Juwaheer, "Relationships and impacts of service quality, perceived value, customer satisfaction, and image: an empirical study," The Service Industry Journal, vol. 29, no. 2, pp. 111-125, 2009.

[24] M. Raymond and J. F. Tanner, "Maintaining customer relationship in direct sales: stimulating repeat purchase behaivour," Journal of Personal Selling \& Sale Management, vol. 14, no. 3, pp. 67-76, 1994.

[25] P. R. Smith, Marketing Communications: An Integrated Approach, 2nd ed. London: Kogan Page, 1999.

[26] Y. Li, L. Xu, and D. Li, "Examining relationships between the return policy, product quality, and pricing strategy in online direct selling," International Journal of Production Economics, vol. 144, no. 2, pp. 451-460, August 2013.

[27] A. Dwivedi, "Brand extension feedback effects: A holistic framework," Brand Management, vol. 17, no. 5, pp. 328-342, 2010.

[28] W. Lin, "Construction of on-line consumer behavior models: a comparative study of industries in Taiwan," International Journal of Commerce and Management, vol. 18, no. 2, pp. 123-149, 2008.
[29] M. W. C. So, T. N. D. Wong, and D. Sculli, "Factors affecting intentions to purchase via the internet," Industrial Management and Data System, vol. 105, no. 9, pp. 1225-1244, 2005.

[30] C. Jayawardhena, "Personal values' influence on e-shopping attitude and behavior," Internet Research, vol. 4, no. 12, pp. 127-138, 2004.

[31] B. C. Y. Lee, "The determinants of consumer attitude toward service innovation-the evidence of ETC system in Taiwan," Journal of Service Marketing, vol. 26, no. 1, pp. 9-19, 2012.

[32] F. N. Ado-Yobo, C. Njiru, and M. Sohail, "Determinants of households' intention to pay for improved water services: an application of the theory of reasoned action," Journal of Water Supply: Research and Technology, vol. 55, no. 6, pp. 419-425, 2006.

[33] E. Martinez, Y. Polo, and L. de Chernatony, "Effect of brand extension strategies on brand image: A comparative study of the UK and Spanish markets," International Marketing Review, vol. 25, no. 1, pp. 107-137, 2008.

[34] S. Lada, G. H. Tanakinjal, and H. Amin, "Predicting intention to choose halal products using theory of reasoned action," International Journal of Islamic and Middle Eastern Finance and Management, vol. 2, no. 1, pp. 66-76, 2009.

[35] L. Schiffman, S. T. Thelen, and E. Sherman, "Interpersonal and political trust: modeling levels of citizens' trust," European Journal of Marketing, vol. 44, no. 3/4, pp. 369-381, 2010.

[36] U. Sekaran and R. Bougie, Research Methods for Business, 5th ed., U.K.: John Wiley and Sons, 2010.

[37] J. F. Hair, W. C. Black, B. J. Babin, and R. E. Anderson, Multivariate Data Analysis, $7^{\text {th }}$ ed, Upper Saddle River, NJ: Prentice Hall, 2010.

[38] P. Poon, G. Albaum, and P. S. Chan, "Managing trust in direct selling relationships," Marketing Intelligence \& Planning, vol. 30, no. 5, pp. 588-603, 2012.

[39] M. Omar, R. L. Williams, and D. Lingelbach, "Global brand market-entry strategy to manage corporate reputation," Journal of Product \& Brand Management, vol. 18, no. 3, pp. 177-187, 2009.

[40] D. Xardel, The Direct Selling Revolution. Understanding the Growth of the Amway Corporation, New York: Blackwell Publishing, 1993, pp. $1-2$.

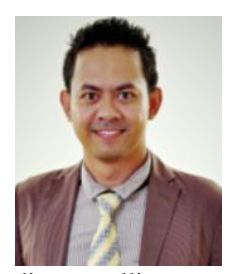

Prasit Rattanaphan was born in Nakhon $\mathrm{Si}$ Thammarat, Thailand on August 13, 1977. He holds a Ph.D degree in marketing from OYA Graduate Business College of Business, University Utara Malaysia. He is the director of Communication Office and a lecturer of Hatyai Business School, Hatyai University, Songkhla, Thailand. He is a columnist of Thai newspapers and speaker in term of marketing, direct selling, services, and branding for SMEs and Direct Selling Companies. His research interests are related to marketing especially, consumer behaviour, sales management, multi-Level marketing (MLM), service marketing and corporate image.

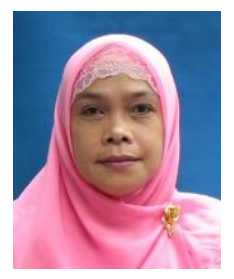

Nik Kamariah Nik Mat is a professor of marketing in OYA Graduate Business College of Business, University Utara Malaysia. She holds a Ph.D degree in marketing from University of Aston in Birmingham, England, UK. Her research interests include sales management, professional selling, multi-Level marketing (MLM), consumer behavior and relationship marketing. 